УДК 347.9

DOI https://doi.org/10.32837/pyuv.v0i1.725

\author{
С. В. Дяченко \\ orcid.org/0000-0002-0104-2769 \\ кандидат юридичних наук, доцент, \\ доцент кафедри цивільного права та процесу \\ Навчально-наукового інституту права \\ Університету державної фіскальної служби України
}

Л. В. Гонцовська

orcid.org/0000-0001-9747-7689

студентка III курсу

Навчально-наукового інституту права

Університету державної фіскальної служби України

\title{
РОЗМЕЖУВАННЯ ЮРИСДИКЦЙ СУДІВ ПРИ ВИРІШЕННІ СПОРІВ, ЩО ВИНИКАЮТЬ ІЗ ДОГОВОРУ ЕМФІТЕВЗИСУ: СУДОВА ПРАКТИКА
}

Постановка проблеми. Нині в цивілістиці досить важливим завданням є дослідження правового регулювання обігу земельних ділянок. У законодавстві України існує не тільки право власності на земельні ділянки, а й обмежені речові права на них, серед яких важливе місце займає право користування чужою земельною ділянкою для сільськогосподарських потреб (емфітевзис). 3 огляду на це стає важливим захист емфітевтичних прав у судовому порядку. Нині ж у цивільному законодавстві України існуе тільки одна підстава для набуття права користування чужою земельною ділянкою для сільськогосподарських потреб, і це договір емфітевзису, від суб'єктного складу якого залежить юрисдикція суду, який буде вирішувати спір, що виникає 3 цього договору. I тому досить важливим завданням є дослідження суб'єктного складу договорів емфітевзису та юрисдикції вирішення спорів, що виникають між ними. Крім цього, існує певна недосконалість правового регулювання цього цивільно-правового інституту, оскільки він регламентується лише ст. 407-412 Цивільного кодексу України та ст. 102-1 Земельного кодексу України, які ще й $\mathrm{e}$ майже ідентичними і не зачіпають усіх питань, які можуть виникати на практиці. Через це у судовій практиці можна помітити велику кількість спорів, що виникають із зазначеного договору. Так, 31 січня 2021 року по 1 квітня 2021 року в Єдиному державному реєстрі судових рішень налічується 1150 справ, пов'язаних з емфітевзисом.

Аналіз останніх досліджень і публікацій. Окремі аспекти емфітевзису були порушені у працях Д. Грімма, О. Дзери, I Новицького, О. Підопригори, С. Погрібного, В. Уркевича, Т. Харитонової, В. Хвостова, О. Шуміло, О. Яворської та інших. Серед видів наукової продукції в цьому напрямі значне місце посідають монографії. Наприклад: Н. Канцедал «Дискусійні аспекти відображення емфітевзису в системі обліку господарюючого суб'єкта» - 2018; Т. Харитонова «Оформлення речових прав на земельну ділянку, відмінних від права власності» - 2013; Г Харченко «Основи речового права в Цивільному кодексі України» 2019. При цьому розглядалися переважно загальні питання правового регулювання емфітевзису та договору емфітевзису. Таким чином, не всі аспекти цієї проблематики за останні роки вивчені належним чином, наприклад аналіз судової практики розгляду спорів, що виникають із договору емфітевзису, і підпорядкування їх для вирішення різним судам (цивільним, господарським, адміністративним). Тому названа тема все одно потребує

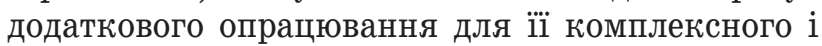
повного розуміння. Вищезазначеним зумовлюється актуальність вибраної для дослідження теми.

Метою статті є з'ясування важливості захисту емфітевзису в судовому порядку, визначення суб'єктного складу договорів емфітевзису та юрисдикції вирішення між ними спорів, а також аналіз судової практики.

Виклад основного матеріалу. Свій початок емфітевзис бере з античних часів, і в римському праві він вперше з'явився не пізніше III ст. н.е. Якщо розглядати емфітевзис у римському цивільному праві, то Г. Пухта про емфітевзис пише, що це право на призначену для землеробства земельну ділянку для повного користування нею, супроводжуване навіть фактичним володінням, так що існування чужого права власності на цю ділянку виявляється лише з деяких обов'язків, які лежать на емфітевті щодо власника $[1$, с. 456]. У свою чергу Ю. Барон говорить про емфітевзис як речове, спадкове і відчужуване, повне право користування і вилучення плодів, встановлене на чужій сільськогосподарській ділянці (у порядку виключення і на будівлю) за певну орендну плату і без жодних обмежень, крім лише того, щоб ділянка 
не була приведена до гіршого проти колишнього стану [2, с. 453]. На нашу думку, зазначені визначення мають право на існування і в сучасному цивільному законодавстві України.

Варто зазначити, що за цивільним законодавством України емфітевзис можна визначити як відчужуване речове право користування чужою земельною ділянкою для сільськогосподарських потреб.

Т.Є. Харитонова запевняє, що емфітевзис походить із договірних відносин. Тобто між власником земельної ділянки та її потенційним користувачем уже існують певні відносини щодо земельної ділянки [3, с. 142-144].

Відповідно до ч. 1 ст. 626 Цивільного кодексу України, договором є домовленість двох або більше сторін, спрямована на встановлення, зміну або припинення цивільних прав та обов' язків [4]. Сдина підстава набуття права емфітевзису і його сторони закріплені в нормі Цивільного кодексу України, а саме відповідно до ч. 1 ст. 407 цього кодексу право користування чужою земельною ділянкою встановлюється договором між власником земельної ділянки й особою, яка виявила бажання користуватися цією земельною ділянкою для сільськогосподарських потреб [4]. Завдяки цьому можна стверджувати, що договір емфітевзису - це договір, за яким одна сторона (власник) передає належне їй право володіння і користування земельною ділянкою виключно для сільськогосподарських потреб другій стороні (землекористувачу).

Щодо назви договору, то можна застосовувати такі: договір емфітевзису, договір про надання права користування чужою земельною ділянкою для сільськогосподарських потреб, договір про встановлення емфітевзису. Різні за формулюванням, але всі однакові за суттю [5, с. 3]. Нами ж буде використовуватися назва "договір емфітевзису».

Далі потрібно відзначити те, що право користування земельною ділянкою на умовах емфітевзису є обмеженим і цільовим, оскільки у разі встановлення емфітевзису власник передає право володіння й користування, при цьому залишаючи за собою право власності. Крім цього, договір емфітевзису можна визначити як консенсуальний, окільки для виникнення емфітевтичного права не потребується передача земельної ділянки. Відповідно до ч. 5 ст. 626 Цивільного кодексу України, договір є відплатним, якщо інше не встановлено договором, законом або не випливає із суті договору [4]. А тому можна припустити, що договір емфітевзису є відплатним, якщо його безоплатність прямо не передбачена у самому договорі. Можна додати, що не є обов'язковим, але договір емфітевзису може бути нотаріально посвідчений за бажанням однієї із сторін.

Згідно з ч. 1 та ч. 2 ст. 412 Цивільного кодексу України, підставами припинення права користування земельною ділянкою для сільськогосподарських потреб (емфітевзису) є: поєднання в одній особі власника земельної ділянки та землекористувача; сплив строку, на який було надано право користування; викуп земельної ділянки у зв'язку із суспільною необхідністю; за рішенням суду в інших випадках, встановлених законом [4].

Важливим $є$ те, що за стільки років існування емфітевзису в Україні так досі ні цивільне, ні земельне законодавство не встановлює певної закріпленої форми договору емфітевзису, однак, виходячи із того, що емфітевзис підлягає державній реєстрації, можна зробити висновок, що форма цього договору має бути простою письмовою. Ми вважаємо, що доцільно було б розробити Типовий договір емфітевзису. У такому разі на практиці з певних питань виникало б менше спорів і значно менше звернень до суду. Наприклад, вказати під час розроблення Типового договору положення про те, що розірвання договору допускається лише за згодою сторін, якщо інше не передбачено договором, а вже тільки за відсутності взаємної згоди можливе звернення до суду. I, можливо, передбачити ще деякі випадки, в яких спір може бути вирішений тільки в неюрисдикційній формі.

3 огляду на це, слід розглянути захист емфітевзису в судовому порядку. Насамперед зазначимо, що юрисдикційна форма захисту - зумовлена законом діяльність компетентних органів щодо захисту права, що полягає у встановленні фактичних обставин цивільної справи, застосуванні відповідних норм права, визначенні способів захисту права та прийнятті рішення [6, с. 15]. Таким чином, юрисдикційною формою буде саме судовий захист. Окреслимо деякі випадки, через які можуть виникати спори між сторонами договору емфітевзису, і важливість їх правильного розгляду в судовому порядку для захисту емфітевтичних прав.

По-перше, із ст. 407 Цивільного кодексу України та ст. 102-1 Земельного кодексу України не зовсім зрозуміло, якої категорії землі передаються на праві емфітевзису, але зазначено, що метою їх подальшого використання мають бути сільськогосподарські потреби. Відсутність чіткої законодавчої вказівки може споріднювати емфітевзис та деякі види земельного сервітуту. Судова практика свідчить про досить часті випадки нерозуміння особами різниці між договором емфітевзису і договором оренди землі. Тому в таких випадках між сторонами можливе виникнення непорозумінь, які можуть розглядатися в судовому порядку.

По-друге, неврегульованість змісту договору емфітевзису, його форми та суб'єктного складу породжує проблеми неефективного землекористування, що теж у певних випадках може стати підставою виникнення спору. На рахунок цього T. Є. Харитонова говорить, що сьогодні формується хибна практика укладення договорів 
емфітевзису за участю іноземців та осіб без громадянства, що мотивується тим, що при укладанні зазначеного договору ці категорії громадян набувають не право власності, а право користування [3, с. 142-144]. I взагалі, як наголошує науковець, іноземці та особи без громадянства можуть користуватися земельними ділянками для сільськогосподарських потреб тільки на умовах договору оренди, а не договору емфітевзису.

По-третє, можливе звернення до суду з вимогою стягнення заборгованості за договором емфітевзису, визнання договору емфітевзису недійсним та скасування запису про державну реєстрацію договору емфітевзису, використання земельної ділянки не за призначенням і багато інших.

Вищезазначені спори, які можуть виникати 3 договору емфітевзису, будуть вирішуватися в юрисдикційній формі залежно від їх суб'єктного складу. Найбільш поширеним є укладення договору емфітевзису між громадянами - власниками земельних ділянок та сільськогосподарськими підприємствами [7, с. 121]. Сільськогосподарські підприємства можуть набувати в користування без будь-яких обмежень, в тому числі і на умовах емфітевзису, землі сільськогосподарського призначення для ведення товарного сільськогосподарського виробництва [8, с. 10]. Ми вважаємо, що законодавець забув вказати те, що на умовах договору емфітевзису можуть надаватися земельні ділянки для сільськогосподарських потреб фермерським господарствам, оскільки такі юридичні особи не зазначені у відповідних статтях Цивільного кодексу України та Земельного кодексу України, але і чіткої заборони їм користуватися земельними ділянками на умовах договору емфітевзису немає в законодавстві. На додаток до цього практика показує, що велика кількість фермерських господарств все-таки набувають право емфітевзису.

Вище ми зазначили, що суб'єктним складом договорів емфітевзису може бути, з однієї сторони, власник - фізична особа, а з іншої сторони - землекористувач - юридична особа, однак на стороні власника може бути і юридична особа. У такому разі двома сторонами будуть юридичні особи або ж юридична особа і фізична особа відповідно. Також однією із сторін або ж обома сторонами можуть бути фізичні особи-підприємці. Таким чином, від суб’єктів, які уклали договір емфітевзису, буде залежати юрисдикція суду, який буде розглядати справу у разі спору між сторонами. Розглянемо, в якому випадку і яка юрисдикція буде.

Для початку варто зауважити, що у разі недодержання юрисдикції чи підсудності наслідком буде скасування вищим судом рішення або ж навіть засвідчення порушення ст. 6 Свропейської конвенції з прав людини Свропейського суду 3 прав людини. Тому, як бачимо, це питання є дуже важливим, тому що на практиці особи не завжди знають, до якого саме суду потрібно звертатися, коли у них виникають спори, предметом яких $€$ договір емфітевзису.

Відповідно до Постанови Пленуму Верховного Суду України «Про практику застосування судами земельного законодавства під час розгляду цивільних справ», за загальним правилом розмежування компетенції судів із розгляду земельних та пов'язаних із земельними відносинами майнових спорів відбувається залежно від суб'єктного складу їх учасників. Ті земельні та пов' язані із земельними відносинами майнові спори, сторонами в яких є юридичні особи, а також громадяни, що здійснюють підприємницьку діяльність без створення юридичної особи і в установленому порядку набули статус суб'єкта підприємницької діяльності, розглядаються господарськими судами, а всі інші - в порядку цивільного судочинства, крім спорів, зокрема, щодо оскарження рішень, дій чи бездіяльності суб'єктів владних повноважень під час реалізації ними управлінських функцій у сфері земельних правовідносин, вирішення яких віднесено до компетенції адміністративних судів [9].

Отже, оскільки з договору емфітевзису виникають земельні відносини, то наведена Постанова застосовується і до нього. 3 цього можна зробити висновок, що спори, які виникають із договору емфітевзису і у яких сторонами є виключно юридичні особи або фізичні особи-підприємці, будуть підлягати вирішенню в порядку господарського судочинства. Якщо ж сторонами договору емфітевзису або однією із сторін є фізичні особи, то такі спори вирішуватимуться судами цивільної юрисдикції. А у випадку спорів щодо оскарження рішень, дій чи бездіяльності суб'єктів владних повноважень з приводу договору емфітевзису буде розгляд в порядку адміністративного судочинства. Однак, крім того, юрисдикція залежить не тільки від суб’єктів, а й від самого спору, тому в певних випадках спори з договорів емфітевзису можуть вирішуватися і в порядку кримінального судочинства.

Розглянемо на прикладі судової практики, які саме спори, що виникають із такого договору, будуть віднесені до розгляду кожної із зазначених юрисдикцій.

Насамперед розглянемо цивільну юрисдикцію. Потрібно зазначити, що відповідно до ч. 1 ст. 19 Цивільного процесуального кодексу України суди розглядають у порядку цивільного судочинства справи, що виникають із цивільних, земельних, трудових, сімейних, житлових та інших правовідносин, крім справ, розгляд яких здійснюється в порядку іншого судочинства [10]. У процесі розгляду цієї теми ми помітили, що найбільше судових рішень стосовно емфітевзису саме у формі цивільного судочинства. 
Наведемо, до прикладу, постанову Касаційного цивільного суду у складі Верховного Суду від 10 січня 2019 року у справі № $573 / 624 / 17$-ц. 3 неї видно, що виник спір між ТОВ «Саан-Агро» і Особою 5 та між Особою 5 і ФГ «Снігірьова О.А.». Він полягав у тому, що особи не могли зрозуміти, в якому ж випадку був укладений договір емфітевзису, а в якому - оренди. У підсумку Верховний Суд погодився з висновком суду апеляційної інстанції та зазначив, що між ТОВ «Саан-Агро» й Особою 5 укладено договір оренди земельної ділянки, що відноситься до зобов'язальних правовідносин, а між Особою 5 і ФГ «Снігірьова О. А.» - договір емфітевзису, що відноситься до речового права [11]. Ми ж можемо тільки додати, що сьогодні на практиці справді досить часто виникають ситуації, коли землекористувачі не чітко розуміють, у чому різниця між емфітевзисом і орендою земельної ділянки, що стає підставою для виникнення спору. Проаналізувавши судову практику, можна побачити, що більшість таких спорів вирішуються в порядку цивільного судочинства. А із зазначеної Постанови зрозуміло, чому спір між особами був віднесений на вирішення до цивільного судочинства, бо стороною є фізична особа.

Перейдемо до розгляду господарської юрисдикції. У процесі дослідження нами було помічено, що найбільша кількість спорів щодо емфітевзису, які вирішувалися судами в порядку господарського судочинства, датується 2010 роком, але і зараз теж є. Наприклад, Ухвала Господарського суду Київської області від 14 листопада 2019 року у справі № $910 / 15650 / 19$, де до Господарського суду міста Києва надійшла заява б/н від 04.11.2019 Товариства з обмеженою відповідальністю «Агро-Проперті» про забезпечення позову. Заявник зазначає, що Товариство з обмеженою відповідальністю "Агро-Проперті» має намір звернутися до суду з позовом до Товариства з обмеженою відповідальністю “Агросленд» про скасування записів у Державному реєстрі речових прав на нерухоме майно, про інше речове право (право користування земельною ділянкою для сільськогосподарських потреб, емфітевзис) [12]. Із суті справи одразу зрозуміло, чому вона підсудна господарській юрисдикції. А все через те, що сторонами в ній є тільки юридичні особи.

Продовжуючи, заявник (Товариство з обмеженою відповідальністю "Агро-Проперті») просить суд вжити заходів забезпечення позову (який буде поданий у майбутньому) шляхом заборони усім суб'єктам державної реєстрації речових прав вчиняти будь-які реєстраційні дії щодо запису в Державному реєстрі речових прав на нерухоме майно про інше речове право. Суд не знаходить підстав для задоволення заяви про забезпечення позову, що подана до пред'явлення позову, оскільки майбутній позов, який має намір подати заявник, стосується лише реєстраційних дій, вчинених державним реєстратором на підставі відповідних правочинів, вчинення яких та набрання чинності (юридичної сили) яких безпосередньо залежить від державної реєстрації юридичного факту, що породжений цим правочином [12]. А тому у підсумку суд відмовив Товариству з обмеженою відповідальністю «Агро-Проперті» у забезпеченні позову. Хотіли б додати, що, крім таких спорів, у процесі розгляду цього питання ми помітили, що у порядку господарського судочинства вирішується багато спорів щодо стягнення заборгованості з осіб, які користуються земельною ділянкою на праві емфітевзису.

Варто звернути увагу на те, що під час розгляду спорів про визнання недійсними правочинів варто пам'ятати, що зміст окремих видів договорів визначається спеціальними законами. Наприклад, глава 54 Цивільного кодексу України передбачає, що зміст договорів купівлі-продажу повинен включати предмет договору, права та обов'язки сторін, момент виникнення права власності на предмет договору, порядок здійснення розрахунків. Однак у статті 132 Земельного кодексу України зміст договору про перехід права власності на земельну ділянку включає набагато більше пунктів. Він повинен містити: вид договору; предмет договору (характеристику земельної ділянки); назву сторін; документ, що підтверджує право власності на земельну ділянку; відомості про відсутність заборон на відчуження земельної ділянки; відомості про відсутність або наявність обмежень щодо використання вемельної ділянки за цільовим призначенням (застава, оренда, емфітевзис, сервітути тощо); договірну ціну; зобов'язання сторін [13 , с. 41]. Це є особливо актуальним 3 огляду на те, що з 1 липня 2021 року в Україні відкривається ринок землі, що дозволить власникам земельних ділянок, обтяжених емфітевзисом, продавати їх.

Наостанок розглянемо адміністративну юрисдикцію. А саме Постанову Третього Апеляційного адміністративного суду від 23 березня 2021 року у справі № 160/3502/20. ОСОБА_1 звернувся до суду з позовом до приватного нотаріуса Кот Любові Іванівни, в якій просив: визнати неправомірними дії приватного нотаріуса Кот Любов Іванівни; визнати недійсним та скасувати у Державному реєстрі прав похідне від права власності право користування земельною ділянкою для сільськогосподарських потреб (емфітевзис), здійсненого на підставі Договору встановлення емфітевзису; стягнути 3 приватного нотаріуса Кот Любов Іванівни на користь ОСОБА_1 моральну шкоду в сумі 100 тисяч гривень [14]. $\overline{\mathrm{y}}$ цьому випадку позивач ОСОБА_1 посилався на те, що укладення договору емфітевзису між ним і ОСОБОЮ_2, яке посвідчив 
зазначений нотаріус, було здійснено на підставі недійсного паспорту ОСОБИ_2. Однак суд, дослідивши всі обставини, залишив позов без задоволення. Цей спір віднесений до розгляду суду адміністративної юрисдикції, оскільки сторонами є, з одного боку (а саме позивачем), фізична особа (ОСОБА_1), а з другого (відповідачем), суб’єкт владних повноважень, який реалізував управлінські функції у сфері земельних правовідносин (приватний нотаріус, який нотаріально посвідчував договір емфітевзису).

Висновки. Підсумовуючи все вищесказане, можна зробити такі висновки. Емфітевзис як вид речового права регулюється Цивільним кодексом України та Земельним кодексом України, положення яких щодо цього виду права користування земельною ділянкою є майже ідентичними. Нині законодавство має певні прогалини у регулюванні емфітевзису, що слугують причиною для виникнення земельних спорів (у цьому випадку саме спорів щодо права користування чужою земельною ділянкою для сільськогосподарських потреб (емфітевзис)), які залежно від суб'єктного складу будуть підлягати вирішенню в порядку цивільного, господарського або адміністративного судочинства. Аналізуючи судову практику в Єдиному державному реєстрі судових рішень, можна бачити, що найбільше спорів, які виникають із договору емфітевзису, розглядаються в порядку цивільного судочинства. А саме в такому порядку будуть розглядатися і вирішуватися спори, де однією або двома сторонами є фізична особа. Розмежування юрисдикцій судів під час вирішення спорів, що виникають з договору емфітевзису, можуть потребувати майбутніх досліджень. Тому що з кожним днем кількість таких спорів збільшується, а їх виникненням можуть слугувати нові підстави.

\section{Jimepamypa}

1. Пухта Г.Ф. Курс римского гражданского права. T.1. M., $1874.550 \mathrm{c}$.

2. Барон Ю. Система римского гражданского права. СПб., 2005. 1100 с.

3. Харитонова T.Є. Набуття громадянами права на чужу земельну ділянку шляхом укладання договору емфітевзису. Порівняльно-аналітичне право. № 1. 2014. C. 140-144.

4. Цивільний кодекс України : Закон України від 16.01.2003 № 435-IV. Відомості Верховної Ради України (BBP ). 2003. №№ 40-44. Ст. 356.

5. Саяпіна І.Г. Емфітевзис. Науково-практичний журнал: Мала енциклопедія нотаріуса. 2015. № 3. C. 1-16.

6. Дяченко С.В., Рябченко Ю.Ю, Самілик Л.О. Цивільний процес України: практикул. Ірпінь, 2020. 312 с. (На допомогу студенту УДФСУ).

7. Яворська О. Договір як підстава виникнення права користування чужою земельною ділянкою для сільгосп потреб. Підприємнищтво, господарство і право. 2019. № 6. С. 120-124.
8. Спіцина Л. Законодавчі засади використання земель сільськогосподарського призначення на умовах емфітевзису в Україні. Науково-практичний журнал: Мала енциклопедія нотаріуса. 2017. № 5 (95). С. 7-22.

9. Постанова Пленуму Верховного Суду України «Про практику застосування судами земельного законодавства при розгляді цивільних справ» від 16 квітня 2004 року №7. URL: https://zakon.rada.gov.ua/laws/ show/va007700-04\#Text (дата звернення: 11.04.2021).

10. Цивільний процесуальний кодекс України : Закон України від 18.03.2004 № 1618-IV. Відомості Верховної Ради України (ВВР). 2004. №№ 40-41. №42. Ст. 492.

11. Постанова Касаційного цивільного суду у складі Верховного Суду від 10 січня 2019 року у справі № 573/624/17-ц. Єдиний державний реєстр судових рішень. URL: http://www.reyestr.court.gov.ua/ Review/79298149 (дата звернення: 12.04.2021).

12. Ухвала Господарського суду Київської області від 14 листопада 2019 року у справі № 910/15650/19. Єдиний державний реєстр судових рішень. URL: https://reyestr.court.gov.ua/Review/85616839 (дата звернення: 12.04.2021).

13. Дяченко C.В., Пажетнова I.О. Судова практика розгляду спорів про невідповідність правочинів вимогам законодавства. Журнал Форул права: електрон. наук. фахове вид.. 2017. №3. С. 40-46.

14. Постанова Третього Апеляційного адміністративного суду від 23 березня 2021 року у справі № 160/3502/20. Єдиний державний реєстр судових рішень. URL: https://reyestr.court.gov.ua/ Review/96047390 (дата звернення: 13.04.2021).

\section{Анотація}

Дяченко С. В., Гонцовська Л. В. Розмежування юрисдикцій судів при вирішенні спорів, що виникають із договору емфітевзису: судова практика. - Стаття.

Стаття присвячена з'ясуванню важливості захисту емфітевзису в судовому порядку, визначенню суб'єктного складу договорів емфітевзису та юрисдикції вирішення між ними спорів, а також аналізу судової практики. Визначено поняття «емфітевзису» як відчужуване речове право користування чужою земельною ділянкою для сільськогосподарських потреб. Акцентується увага на тому, що неврегульованість змісту договору емфітевзису, особливо його суб'єктного складу та форми, спричиняє проблему неефективного землекористування. Запропоновано розробити на законодавчому рівні Типовий договір емфітевзису, який допоміг би на практиці зменшити кількість непорозумінь між сторонами. 3 огляду на це, стає важливим захист емфітевзису в судовому порядку. До спорів, які підлягають розгляду в судовому порядку, належать: хибна практика укладення договорів емфітевзису за участю іноземців та осіб без громадянства, вимога стягнення заборгованості за договором емфітевзису, визнання договору емфітевзису недійсним, використання земельної ділянки не за призначенням.

Констатовано, що існує тільки одна підстава набуття права користування чужою земельною ділянкою для сільськогосподарських потреб, і це договір емфітевзису. Від суб'єктного складу договору емфітевзису залежить юрисдикція суду, який буде вирішувати спір. Спори, у яких сторонами є виключно юридичні особи або фізичні особи-підприємці, будуть підлягати вирішенню в порядку господарського судочинства. Якщо ж сторонами договору емфітевзису або однією із сторін є фізичні особи, то такі спори будуть вирішуватися судами цивільної юрисдикції. А у випадку 
спорів щодо оскарження рішень, дій чи бездіяльності суб'єктів владних повноважень із приводу договору емфітевзису буде розгляд у порядку адміністративного судочинства.

Проаналізовано судову практику в Єдиному державному реєстрі судових рішень. Розглянуто судові рішення відповідно до кожної юрисдикції (цивільної, господарської, адміністративної). Визначено, що найбільше спорів, що виникають із договору емфітевзису, розглядаються в порядку цивільного судочинства.

Ключові слова: емфітевзис, договір емфітевзису, юрисдикційна форма захисту, цивільне судочинство, судова практика.

\section{Summary}

Diachenko S. V., Hontsovska L. V. Delimitation of court jurisdictions in resolving disputes arising from the emphyteusis agreement: judicial practice. - Article.

The article is devoted to clarifying the importance of protection of emphyteusis in court, determining the subjective composition of emphyteusis agreements and the jurisdiction of resolving disputes between them, as well as the analysis of judicial practice. The concept of "emphyteusis" is defined as an alienable real right to use someone else's land for agricultural purposes. Emphasis is placed on the fact that the unregulated content of the emphyteusis agreement, especially it is subjective composition and form, causes the problem of inefficient land use. It is proposed to develop at the legislative level a Model Emphyteusis Agreement, which would help in practice to reduce the number of misunderstandings between the parties. Given this, it becomes important to protect emphyteusis in court. Disputes to be considered in court include: wrong practice of concluding emphyteusis agreements with the participation of foreigners and stateless persons, demand for debt collection under the emphyteusis agreement, recognition of the emphyteusis agreement as invalid, misuse of land.

It is stated that there is only one reason for acquiring the right to use someone else's land for agricultural purposes, and that is the emphyteusis agreement. The jurisdiction of the court that will resolve the dispute depends on the subjective composition of the emphyteusis agreement. Disputes in which the parties are exclusively legal entities or natural personsentrepreneurs will be subject to resolution in commercial jurisdiction. If the parties to the emphyteusis agreement or one of the parties are individuals, such disputes will be resolved by courts of civil jurisdiction. And in the case of disputes concerning the appeal of decisions, actions or omissions of the subjects of power over the emphyteusis agreement, will be considered in administrative jurisdiction.

The judicial practice in the Unified State Register of court decisions is analyzed. Judicial decisions in accordance with each jurisdiction (civil, commercial, administrative) are considered. It is determined that most disputes arising from the emphyteusis agreement are considered in civil proceedings.

Key words: emphyteusis, emphyteusis agreement, jurisdictional form of protection, civil proceedings, judicial practice. 